\title{
Tertiary Hyperparathyroidism Secondary to X-linked Hypophosphatemic Rickets
}

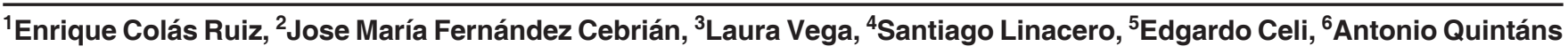

\section{ABSTRACT}

Tertiary hyperparathyroidism is a rare complication of X-linked hypophosphatemic rickets. The surgical treatment is already unclear.

Keywords: Hyperparathyroidism, Parathyroidectomy, X-linked hypophosphatemic rickets.

How to cite this article: Ruiz EC, Cebrián JMF, Vega L, Linacero S, Celi E, Quintáns A. Tertiary Hyperparathyroidism Secondary to X-linked Hypophosphatemic Rickets. World J Endoc Surg 2017;9(1):24-26.

Source of support: Nil

Conflict of interest: None

\section{INTRODUCTION}

X-linked hypophosphatemic rickets (XLHR) is the most common heritable hypophosphatemic disorder. ${ }^{1}$ It results from the combination of impaired renal tubular resorption of phosphate and abnormal vitamin $\mathrm{D}$ regulation in the kidney. ${ }^{2}$ It is associated with inactivating mutations of the Phosphate regulating endopeptidasa homolog, $\mathrm{X}$-linked gene, that encodes a transmembrane endopeptidase, to reduce FGF 23. An increased level of FGF 23 may be responsible for the hyperphosphaturia or low calcitriol levels and skeletal mineralization disorders. ${ }^{3}$

Medical treatment consists of large doses of oral inorganic phosphate and vitamin D supplements, ${ }^{4}$ although long-term treatment may lead to nephrocalcinosis and secondary to tertiary hyperparathyroidism.

\section{CASE REPORT}

A 24-year-old female with XLHR was diagnosed at the age of 14 and she had undergone two corrective osteotomies. She was exposed to long-term oral vitamin D and phosphate supplementation, developing nephrocalcinosis diagnosed by ultrasound without clinical disorders. She

\footnotetext{
1,3-5 Assistant Professor, ${ }^{2,6} \mathrm{Head}$

${ }^{1-6}$ Department of General Surgery, Hospital Universitario Fundación Alcorcón, Alcorcón, Madrid, Spain

Corresponding Author: Enrique Colás Ruiz, Assistant Professor Department of General Surgery, Hospital Universitario Fundación Alcorcón, Alcorcón, Madrid, Spain, Phone: +00916219400 e-mail: ecolas@fhalcorcon.es
}

developed a tertiary hyperparathyroidism with persistent elevation in both serum calcium and parathyroid hormone (PTH) levels at the age of 23.

Two parathyroid imaging with $99 \mathrm{~m}$-Tc-Sestamibi scintigraphy revealed a hyperfunctioning left side parathyroid gland.

Prior to surgical intervention, she was treated with cinacalcet and vitamin D supplements to avoid postoperative hungry bone syndrome (HBS), with PTH levels decreased $200 \mathrm{pg} / \mathrm{mg}$ and serum calcium levels $<10 \mathrm{mg} / \mathrm{dL}$.

The patient underwent bilateral cervical exploration. Intraoperative findings were not correlated with preoperative imaging, with four large orthotopic parathyroid glands, with a particularly large gland in left superior gland.

We performed a total parathyroidectomy with autotransplant in the nondominant forearm, getting a decrease in intraoperative PTH levels to $12 \mathrm{pg} / \mathrm{mL}$.

The pathologic examination results describe all four parathyroid glands as enlarged (weight of: Left superior gland $910 \mathrm{mg}$, left inferior gland $230 \mathrm{mg}$, half right superior gland $30 \mathrm{mg}$, and right inferior gland $90 \mathrm{mg}$ ).

She developed clinical and analytical postoperative hypocalcemia for which she was treated with oral calcium treatment and was maintained on an IV calcium infusion.

She was discharged on postoperative day 7 asymptomatic with oral supplements.

Six months postoperatively, her PTH levels increased with normal calcium and phosphate levels and normal 99m-Tc-Sestamibi scintigraphy. She was managed increasing calcitriol doses and adding oral magnesium. At follow-up, she remained asymptomatic and PTH levels were normal 9 months later, being possible to reduce the calcium and vitamin D. After 3 years, she is still asymptomatic and controlled with small doses of vitamin D, magnesium, and phosphate.

\section{COMMENTARY}

Tertiary hyperparathyroidism secondary to XLRH is a rare complication associated with long-term administration of calcitriol and phosphate salts.

The role of preoperative parathyroid localization including 99m-Tc-sestamibi Single photon emission computed tomography imaging and parathyroid ultrasound is unclear, and its efficacy has been questioned. 
Intraoperative PTH decreasing $>50 \%$ after 10 minutes is highly predictive of successful surgical treatment. ${ }^{5-6}$ In our case, the PTH level dropped from $176 \mathrm{pg} / \mathrm{mL}$ to $12 \mathrm{pg} / \mathrm{mL}$.

The surgical treatment is already unclear, but it is the only effective treatment. The gold standard is neck exploration with identification and excision of abnormal parathyroid tissue, taking a decision with intraoperative findings.

A review of the previously reported cases (Table 1) 5,7-13 shows us the different treatments, the recurrence, complications, and hospital stay.

The literature presents the resection of a single or double adenoma as an effective treatment, but many authors defend that subtotal parathyroidectomy is neces- sary for operative cure. ${ }^{14-19}$ The largest series of surgical management of tertiary hyperparathyroidism associated with XLHR contains six patients: Three had total parathyroidectomy, two had three parathyroid glands resected, one of them required completion parathyroidectomy for recurrent disease, and one had two abnormal parathyroid glands resected, dying in the follow-up. ${ }^{13}$

The size of the resected parathyroid tissue maybe is a predictor of the HBS in patients with XLHR after parathyroidectomy

Surgical management of tertiary hyperparathyroidism secondary to XLHR is still unclear, but it is mandatory for a thorough neck exploration.

Table 1: Previous cases/series presenting tertiary hyperparathyroidism secondary to X-linked hypophosphatemic rickets

\begin{tabular}{|c|c|c|c|c|c|}
\hline Article & Surgery/Pathologic results & Hypocalcemia & Recurrence & Complications & $\begin{array}{l}\text { Hospital } \\
\text { stay }(d)\end{array}$ \\
\hline Crowley et al ${ }^{10}$ & Total hyperparathyroidectomy & Yes & & & 160 \\
\hline \multirow[t]{6}{*}{ Savio et $\mathrm{al}^{7}$} & $\begin{array}{l}+2 \text { gland-excision } \\
\text { ( } 2 \text { adenomas })\end{array}$ & Yes & No & $\begin{array}{l}\text { Died of intracranial } \\
\text { hemorrhage } 8 \text { mo } \\
\text { postoperatively }\end{array}$ & 10 \\
\hline & $\begin{array}{l}3 \text { gland-excision and rigth } \\
\text { hemithyroidectomy ( } 3 \text {-gland } \\
\text { hyperplasia) }\end{array}$ & No (Yes) & Yes & No & $2(+6)$ \\
\hline & $\begin{array}{l}\text { Total parathyroidectomy with } \\
\text { autotransplant ( } 1 \text { adenoma/3- } \\
\text { gland hyperplasia) }\end{array}$ & Yes & No & No & 16 \\
\hline & $\begin{array}{l}\text { Total parathyroidectomy, } \\
\text { thyroidectomy and thymectomy } \\
\text { (4-gland hyperplasia) }\end{array}$ & Yes & No & No & 2 \\
\hline & $\begin{array}{l}\text { Total parathyroidectomy and } \\
\text { left hemithyroidectomy ( } 5 \text {-gland } \\
\text { hyperplasia) }\end{array}$ & No & No & Wound infection & 6 \\
\hline & $\begin{array}{l}3 \text { gland parathyroidectomy } \\
\text { and thymectomy (3-gland } \\
\text { hyperplasia) }\end{array}$ & Yes & No & No & 9 \\
\hline Vázquez et $\mathrm{al}^{8}$ & $\begin{array}{l}1 \text { gland excision previously } \\
1 \text { gland excision and } 1 \text { biopsy } \\
\text { no patologic }\end{array}$ & Yes & Yes & $\begin{array}{l}\text { Died of renal } \\
\text { dysfunction } 6 \text { years } \\
\text { postoperatively }\end{array}$ & \\
\hline Moreno Molina et al ${ }^{9}$ & $\begin{array}{l}\text { (1 adenoma + 1-gland } \\
\text { hyperplasia) }\end{array}$ & No & & & \\
\hline Neal et $\mathrm{al}^{5}$ & $\begin{array}{l}\text { Subtotal parathyroidectomy } \\
\text { (4-gland hyperplasia) }\end{array}$ & Yes & & & 6 \\
\hline Tournis et al $^{11}$ & $\begin{array}{l}\text { Subtotal parathyroidectomy } \\
\text { (4- gland hyperplasia) }\end{array}$ & No & & & \\
\hline Alon et al ${ }^{12}$ & $\begin{array}{l}\text { Total parathyroidectomy } \\
\text { with autotransplant (4-gland } \\
\text { hyperplasia) }\end{array}$ & Yes & & & \\
\hline Mäkitie et al ${ }^{13}$ & $\begin{array}{l}\text { Subtotal parathyroidectomy } \\
\text { (hyperplasia) }\end{array}$ & & & & \\
\hline
\end{tabular}

\section{REFERENCES}

1. DiMeglio LA, White KE, Econs MJ. Disorders of phosphate metabolism. Endocrinol Metab Clin North Am 2000 Sep;29(3):591-609.

2. Lyles KW, Drezner MK. Parathyroid hormone effects on serum 1,25-dihydroxyvitamin D levels in patients with X-linked hypophosphatemic rickets: evidence for abnormal 25-hydroxyvitamin D-1-hydroxylase activity. J Clin Endocrinol Metab 1982 Mar;54(3):638-644.

3. Jonsson KB, Zahradnik R, Larsson T White KE, Sugimoto T, Imanishi Y, Yamamoto T, Hampson G, Koshiyama $H$, Ljunggren $\mathrm{O}$, et al. Fibroblast growth factor 23 in oncogenic osteomalacia and X-linked hypophosphatemia. N Engl J Med 2003 Apr 24;348(17):1656-1663. 
4. Baroncelli GI, Bertelloni S, Sodini F, , Galli L, Vanacore T, Fiore L, Saggese G. Genetic advances, biochemical and clinical features and critical approach to treatment of patients with X-linked hypophosphatemic rickets. Pediatr Endocrinol Rev 2004 Jun;1(4):361-379.

5. Neal MD, Deslouches B, Ogilvie J. The use of pre-operative imaging and intraoperative parathyroid hormone level to guide surgical management of tertiary hyperparathyroidism from $X$-linked hypophosphatemic rickets: a case report. Cases J 2009 Sep 10;2:7572.

6. Haustein SV, Mack E, Starling JR, Chen H. The role of intraoperative parathyroid hormone testing in patients with tertiary hyperparathyroidism after renal transplantation. Surgery 2005 Dec;138(6):1066-1071.

7. Savio RM, Gosnell JE, Posen S, Reeve TS, Delbridge LW. Parathyroidectomy for tertiary hyperparathyroidism associated with X-linked dominant hypophosphatemic rickets. Arch Surg 2004 Feb;139(2):218-222.

8. Vázquez AR, Parga G de C, Domínguez LP, Fernández CP, Gil PG. Hypophosphatemic rickets in the adult: evolution of an atypical case over 30 years. Cir Esp 2011;89(8):549-551. (Spa)

9. Moreno Molina JA, López Siguero JP, Bueno Fernández A, Martínez-Aedo Ollero MJ, Martínez Valverde A. Tertiary hyperparathyroidism during the treatment of familial hypophosphatemic rickets. An Esp Pediatr 1996 Aug;45(2):193-195. (Spa)

10. Crowley RK, Kilbane M, King TF, Morrin M, O'Keane M, McKenna MJ. Hungry bone syndrome and normalisation of renal phosphorus threshold after total parathyroidectomy for tertiary hyperparathyroidism in X-linked hypophosphataemia: a case report. J Med Case Rep 2014 Mar 4;8:84.

11. Tournis S, Georgoulas T, Zafeiris C, Papalexis C, Petraki K, Lyritis GP. Tertiary hyperparathyroidism in a patient with
X-linked hypophosphatemic rickets. J Musculoskelet Neuronal Interact 2011 Sep;11(3):266-269.

12. Alon U, Newsome H J, Chan JC. Hyperparathyroidism in patients with X-linked dominant hypophosphatemic rickets application of the calcium infusion test as an an indicator for parathyroidectomy. Int J Pediatr Nephrol 1984 Mar;5(1):39-43.

13. Mäkitie O, Kooh SW, Sochett E. Prolonged high-dose phosphate treatment: a risk factor for tertiary hyperparathyroidism in X-linked hypophosphatemic rickets. Clin Endocrinol (Oxf) 2003 Feb;58(2):163-168.

14. Nichol PF, Starling JR, Mack E, Klovning JJ, Becker BN, Chen H. Long-term follow-up of patients with tertiary hyperparathyroidism treated by resection of a single or double adenoma. Ann Surg 2002 May;235(5):673-680.

15. Milas M, Weber CJ. Near-total parathyroidectomy is beneficial for patients with secondary and tertiary hyperparathyroidism. Surgery 2004 Dec;136(6):1252-1260.

16. Triponez F, Kebebew E, Dosseh E, Duh QY, Haszzan M, Noel C, Chertow GM, Wambergue F, Fleury D, Lemaitre V et al. Less-than-subtotal parathyroidectomy increases the risk of persistent/recurrent hyperparathyroidism after parathyroidectomy in tertiary hyperparathyroidism after renal transplantation. Surgery 2006 Dec;140(6):990-997.

17. Triponez F Clark OH, Evenepoel P. Response to "tertiary hyperparathyroidism: is less than a subtotal resection ever appropriate? A study on long-term outcomes". Surgery 2010 Nov;148(5):1044-1045.

18. Pitt SC, Panneerselvan R, Chen H, Sippel RS. Tertiary hyperparathyroidism: is less than subtotal resection ever appropriate? A study of long-term outcomes. Surgery 2009 Dec;146(6):1130-1137.

19. Kebebew E, Duh QY, Clark OH. Tertiary hyperparathyroidism: histologic patterns of disease and results of parathyroidectomy. Arch Surg 2004 Sep;139(9):974-977. 